\title{
Comparative Efficacy of State-of-the-Art and New Biological Stump Treatments in Forests Infested by the Native and the Alien Invasive Heterobasidion Species Present in Europe
}

\author{
Martina Pellicciaro (D), Guglielmo Lione (D), Silvia Ongaro and Paolo Gonthier *(D) \\ Department of Agricultural, Forest and Food Sciences (DISAFA), University of Turin, 10095 Grugliasco, Italy; \\ martina.pellicciaro@unito.it (M.P.); guglielmo.lione@unito.it (G.L.); silvia.ongaro@unito.it (S.O.) \\ * Correspondence: paolo.gonthier@unito.it; Tel.: +39-011-670-8697
}

\section{check for} updates

Citation: Pellicciaro, M.; Lione, G.; Ongaro, S.; Gonthier, P. Comparative Efficacy of State-of-the-Art and New Biological Stump Treatments in Forests Infested by the Native and the Alien Invasive Heterobasidion Species Present in Europe. Pathogens 2021, 10, 1272. https://doi.org/10.3390/ pathogens10101272

Academic Editor: Simon Francis Shamoun

Received: 3 September 2021

Accepted: 1 October 2021

Published: 2 October 2021

Publisher's Note: MDPI stays neutral with regard to jurisdictional claims in published maps and institutional affiliations.

Copyright: (c) 2021 by the authors. Licensee MDPI, Basel, Switzerland. This article is an open access article distributed under the terms and conditions of the Creative Commons Attribution (CC BY) license (https:// creativecommons.org/licenses/by/ $4.0 /)$.

\begin{abstract}
The Heterobasidion annosum species complex includes major fungal pathogens of conifers worldwide. State-of-the-art preventative stump treatments with urea or with commercial formulations of the fungal biological control agent Phlebiopsis gigantea (i.e., Rotstop ${ }^{\circledR}$ ) may become no longer available or are not approved for use in many areas of Europe infested by the three native Heterobasidion species and by the North American invasive H. irregulare, making the development of new treatments timely. The efficacy of Proradix ${ }^{\circledR}$ (based on Pseudomonas protegens strain DSMZ 13134), the cell-free filtrate (CFF) of the same bacterium, a strain of P. gigantea (MUT 6212) collected in the invasion area of $H$. irregulare in Italy, Rotstop ${ }^{\circledR}$, and urea was comparatively investigated on a total of 542 stumps of Abies alba, Picea abies, Pinus pinea, and P. sylvestris in forest stands infested by the host-associated Heterobasidion species. Additionally, 139 logs of $P$. pinea were also treated. Results support the good performances of Rotstop ${ }^{\circledR}$, and especially of urea against the native Heterobasidion species on stumps of their preferential hosts and, for the first time, towards the invasive North American $H$. irregulare on stumps of $P$. pinea. In some experiments, the effectiveness of Proradix ${ }^{\circledR}$ and of the strain of $P$. gigantea was weak, whereas the CFF of $P$. protegens strain DSMZ 13134 performed as a valid alternative to urea and Rotstop ${ }^{\circledR}$. The mechanism of action of this treatment hinges on antibiosis; therefore, further improvements could be possible by identifying the active molecules and/or by optimizing their production. Generally, the performance of the tested treatments is not correlated with the stump size.
\end{abstract}

Keywords: biological control; cell-free filtrate; forest pathogens; Phlebiopsis gigantea; Proradix®; Pseudomonas protegens; Rotstop®; urea

\section{Introduction}

Heterobasidion annosum (Fr.) Bref. sensu lato (s.l.) is a complex of species comprising fungal plant pathogens causing root rots, butt rots and wood decay in coniferous forests of the Northern Hemisphere [1,2]. Annual economic losses caused by H. annosum s.l. in Europe were estimated at EUR 790 million [1] and occur in association with the decrease in wood production and the reduction in wood quality, which are reported as directly correlated to the incidence of the pathogens [3]. In Europe, H. annosum s.l. includes the native species $H$. abietinum Niemelä \& Korhonen, $H$. annosum sensu strictu (s.s.) and $H$. parviporum Niemelä \& Korhonen, mainly associated with Abies alba Mill., Pinus spp., and Picea abies (L.) Karst., respectively [2]. In addition, Italian stone pine (Pinus pinea L.) is located along the western coastline of central Italy is currently challenged by the invasive North American species $H$. irregulare Garbel. \& Otrosina [4,5]. The risk posed by $H$. irregulare to European forestry is high [6]; therefore, the pathogen is recommended for regulation under the European and Mediterranean Plant Protection Organization (EPPO) A2 list. 
Heterobasidion spp. infect their hosts through basidiospores or mycelium. Primary infection occurs when airborne basidiospores released from fruiting bodies land on the surface of freshly cut stumps and germinate, hence producing mycelia able to colonize the stump tissues. Once the root system of the stump is colonized, the mycelium of Heterobasidion spp. spreads to the neighboring heathy trees by means of root contacts and grafts [2]. This second method of spreading is acknowledged as secondary infection. Hence, stumps created during thinnings and cuttings play a crucial role as starters for new infection foci.

Silvicultural, chemical and biological strategies have been designed and tested to control Heterobasidion spp. infections and spreading [2]. Most of the silvicultural methods are based on providing spacing among trees in new plantations, on planning thinnings and cuttings during periods of low sporulation of the pathogens, and on the mechanical removal of stumps of diseased trees, including their root systems [7-11].

Although effective in reducing the risk of new infections, such strategies imply remarkable technical challenges and high costs for their execution; hence, they may be either unfeasible, or scarcely practicable [12-14]. Conversely, chemical or biological treatments applied on freshly cut stumps act as preventative measures targeting primary infection and are recognized as more sustainable than most of the other strategies $[2,13]$.

A large body of literature has been published on the efficacy of urea [10,15-17]. The mechanism of action of urea has been reported as indirect. The urea solution raises the $\mathrm{pH}$ of the stump up to a level that inhibits basidiospore survival and germination [18]. Urea is the only chemical treatment used in practical forestry in Europe. However, the current European regulations might pose some constraints for the future use of urea, unless an extension of its authorization as a pesticide is issued after the deadline of August 2022 [19].

In the attempt to reduce the use of chemicals in forestry, several studies have focused on the selection of microorganisms that may act as biocontrol agents and inhibit Heterobasidion spp. The most successful results were obtained in the field with Phlebiopsis gigantea (Fr.) Jülich, a wood decay basidiomycete outcompeting Heterobasidion spp. thanks to its rapid colonization of the stump surface [12,16,17,20-28].

Phlebiopsis gigantea strains patented as Rotstop ${ }^{\circledR}$ are widely used in practical forestry both in Europe and North America [13,29], although neither such treatment, nor other products based on $P$. gigantea, are registered for use in southern European countries. Most of the results currently available on the efficacy of $P$. gigantea originate from experiments conducted against $H$. parviporum on $P$. abies, although information about the performance of $P$. gigantea against other Heterobasidion spp. on stumps of other tree species, i.e., A. alba, $P$. pinea and P. sylvestris, are still scarce. Moreover, few studies dealt with the comparative assessment of the efficacy of $P$. gigantea and urea on stumps $[16,24,28,30]$.

As a result of preliminary studies, the bacterial biocontrol agent Pseudomonas protegens (strain DSMZ 13134), patented as Proradix ${ }^{\circledR}$, proved its efficacy against Heterobasidion spp. [31-33]. The production of antibiotics and diffusible antifungal compounds allows P. protegens (strain DSMZ 13134) to inhibit the growth of Heterobasidion spp., as suggested by the outcomes of trials carried out by using the cell-free filtrate (CFF) of P. protegens (strain DSMZ 13134) [33]. Although promising, treatments based on P. protegens (strain DSMZ 13134) still need to be tested against all Heterobasidion species on stumps of their preferential hosts. In fact, so far, available data about $P$. protegens are limited to a small-scale pilot study on stumps of $P$. abies.Stump diameter influences the colonization process of Heterobasidion spp. [34,35]. It has been suggested that large areas of heartwood might create more opportunities for H. parviporum infection in P. abies [11]. However, in several tree species, sapwood is much more extensively infected by Heterobasidion spp. than heartwood [36], which is consistent with the observation that the fungus can establish even in small $(<2 \mathrm{~cm})$ stumps [37]. Although the effects of stump size on primary infections by Heterobasidion spp. have been investigated, the relationship between the treatment efficacy and the stump size has received little attention despite its potential importance in practical forestry [30].Comparative studies contrasting the effectiveness of chemical and biological 
treatments on freshly cut stumps are advocated to design effective and sustainable control measures against Heterobasidion spp. on different host species present in Europe [28], taking into account that the level of efficacy of treatments may vary depending on climate and on local environmental conditions [38,39]. This issue is of the utmost importance not only in relation to the alien species $H$. irregulare threatening $P$. pinea across its invasion area in central Italy, but also for southern European countries, where treatments against Heterobasidion spp. are either not registered, or will be soon revoked. The aims of this study were to compare the efficacy of Proradix ${ }^{\circledR}$, the CFF of P. protegens strain DSMZ 13134, the strain of P. gigantea MUT 6212 collected on P. pinea in the H. irregulare invasion area in central Italy and screened for its biocontrol potential [40], the biological control agent Rotstop $^{\circledR}$, and the chemical control agent urea as stump treatments in forests of $A$. alba, P. abies, P. pinea, and P. sylvestris each infested by their own host-associated Heterobasidion species (i.e., H. abietinum, H. parviporum, H. irregulare, $H$. annosum s.s., respectively). Our experiments were carried out in two of the main ecoregions where the above cited hosts of Heterobasidion spp. grow, namely, the Alps (for A. alba, P. abies, and P. sylvestris) and the Mediterranean area (for $P$. pinea) [41,42]. To further investigate the efficacy of treatments against $H$. irregulare, an experiment was also set up in the field using $P$. pinea logs. An additional and final goal was to explore the effect of stump size on treatment efficacy.

\section{Results}

2.1. Comparative Efficacy of Treatments in Stumps of Abies alba, Picea abies, Pinus pinea and P. sylvestris

Stumps of $A$. alba treated and sampled were as follows: 24 control stumps sprayed with sterile water, 22 stumps treated with Proradix ${ }^{\circledR}, 23$ with CFF, 23 with P. gigantea MUT 6212,22 with Rotstop ${ }^{\circledR}$ and 21 with urea. Isolates obtained from control stumps of $A$. alba were all typed as $H$. abietinum. Incidence and areas colonized by Heterobasidion spp. on wood discs sampled from stumps are shown in Figure 1. In the Figure 1 barplots, each bar refers to a cluster of treatments and shows the related overall incidence of Heterobasidion spp. Treatments included within the same cluster are not associated with significant differences $(p>0.05)$, whereas treatments belonging to different clusters did result in significant differences $(p<0.05)$ of the incidence of Heterobasidion spp. Abbreviations listed under the bars indicate the treatments included within the corresponding cluster. In the dotcharts of the same figure, point marks show the average areas colonized by Heterobasidion spp. for each treatment. In both barplots and dotcharts, different letters indicate significant differences of the associated values $(p<0.05)$, and error bars refer to the $95 \%$ confidence intervals. The incidence of the pathogen was significantly $(p<0.05)$ higher in $A$. alba control stumps $(95.8 \%)$ than in stumps treated with biological products $(63.3 \%)$, that clustered together and separately from stumps treated with urea (9.5\%) (Figure 1a). All treatments resulted in a significant reduction in area colonized by the pathogen compared to controls (Figure $1 b)$. Urea provided the best performance among treatments $(0.3 \%$ of area colonized by the pathogen), whereas stumps treated with P. gigantea MUT 6212 and Rotstop®resulted in a less severe infection of stumps $\left(10.7 \%\right.$ and $11.0 \%$, respectively) compared to Proradix ${ }^{\circledR}$ and CFF (15.4\% and $24.2 \%$, respectively).

Stumps of $P$. abies treated and sampled were as follows: 21 control stumps sprayed with sterile water, 20 stumps treated with Proradix ${ }^{\circledR}, 21$ with CFF, 21 with P. gigantea MUT 6212,21 with Rotstop ${ }^{\circledR}$ and 21 with urea. Isolates obtained from control stumps of P. abies were all typed as $H$. parviporum. The incidence of the pathogen was significantly higher in control stumps and in stumps treated with Proradix ${ }^{\circledR}(60.0 \%)$ than in the other treatments (25.8\%) (Figure 1c). In P. abies stumps, all treatments resulted in areas colonized by the pathogen significantly smaller than in controls (Figure 1d). 

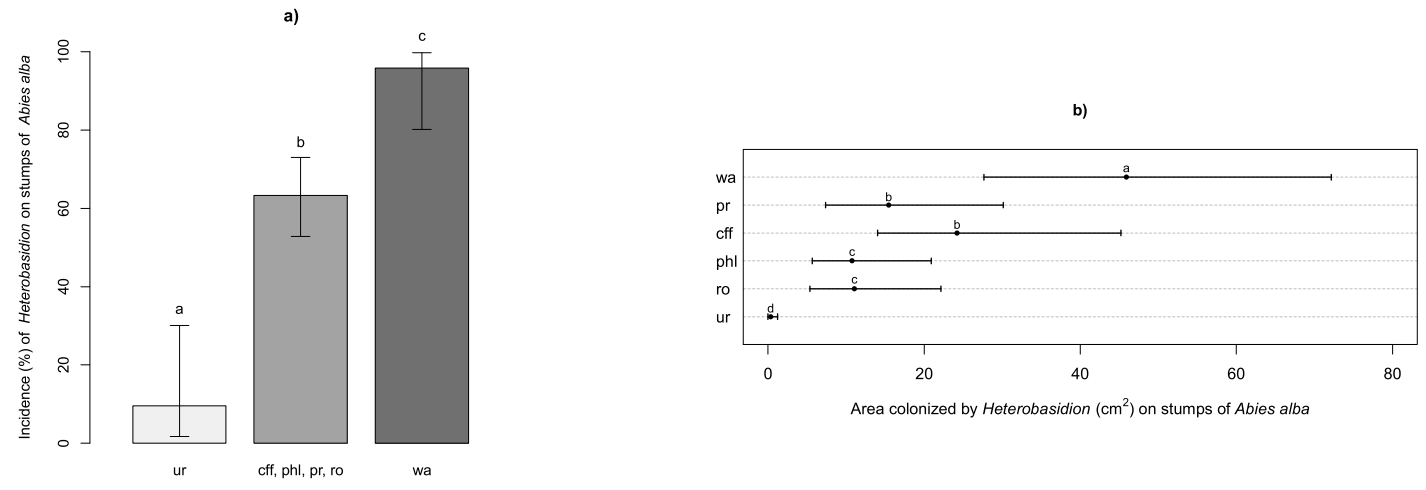

c)
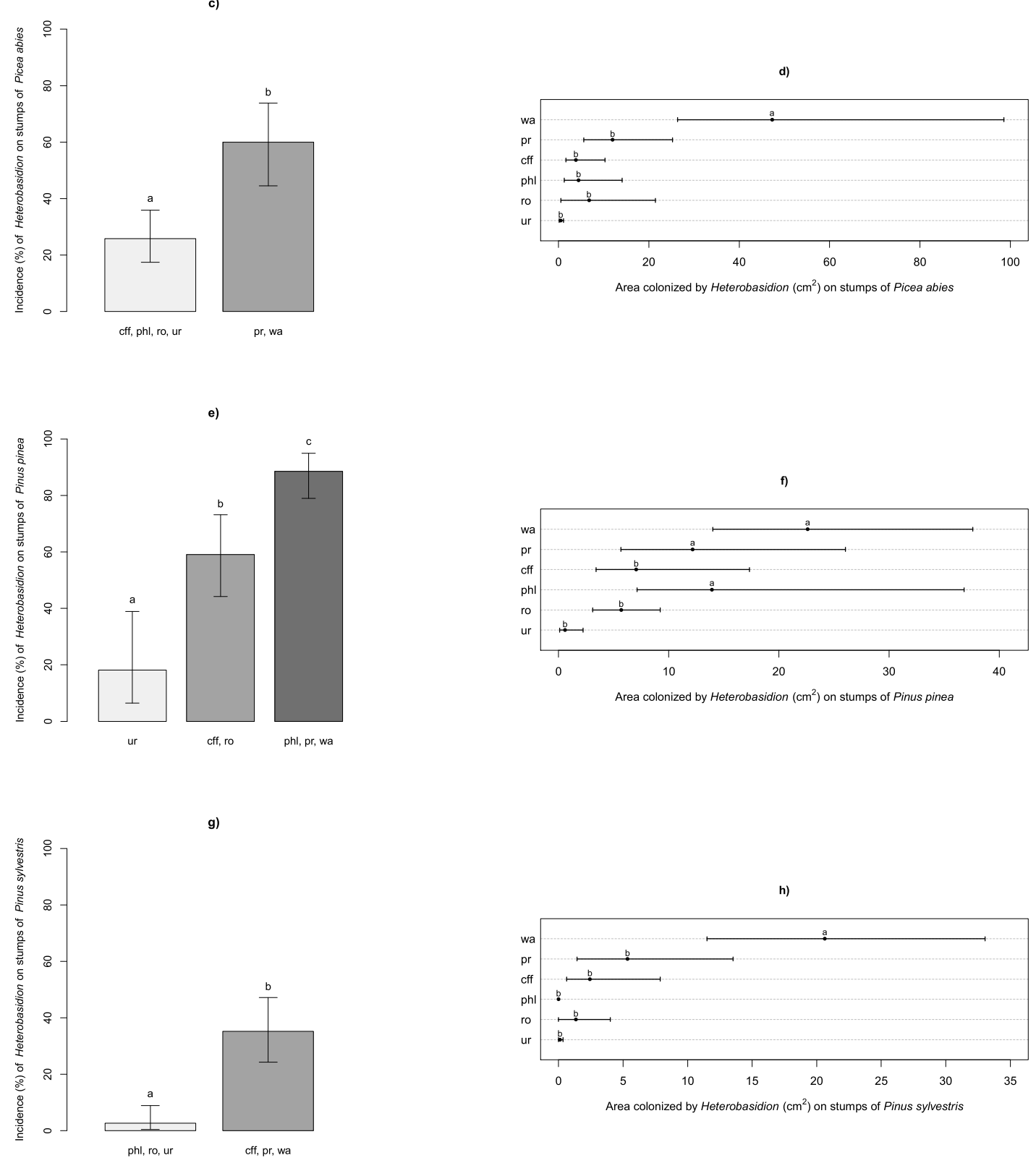

h)

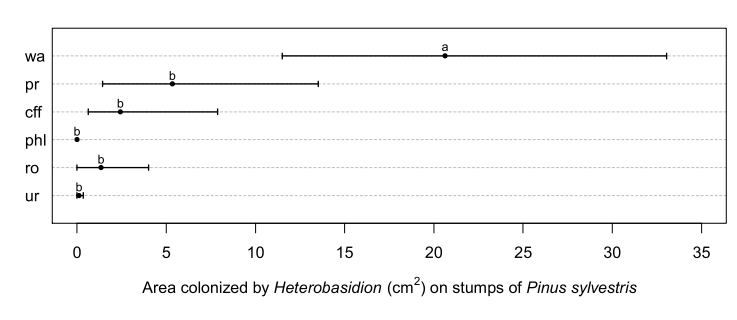

Figure 1. Barplots of the incidence (\%-left panels) and dotcharts of the areas colonized by Heterobasidion spp. ( $\mathrm{cm}^{2}$ —right panels) on treated stumps of Abies alba (panels (a,b)), Picea abies (panels (c,d)), Pinus pinea (panels $(\mathbf{e}, \mathbf{f})$ ), P. sylvestris (panels $(\mathbf{g}, \mathbf{h}))$. Treatment abbreviations: wa-water; pr-Proradix ${ }^{\circledR}$; cff-cell-free filtrate; phl一Phlebiopsis gigantea MUT 6212; ro-Rotstop ${ }^{\circledR}$; and ur-urea. For details, refer to the text. 
Stumps of $P$. pinea treated and sampled were as follows: 25 control stumps sprayed with sterile water, 23 stumps treated with Proradix ${ }^{\circledR}, 22$ with CFF, 22 with P. gigantea MUT 6212, 22 with Rotstop ${ }^{\circledR}$ and 22 with urea. Isolates obtained from control stumps of $P$. pinea were all typed as H. irregulare. In P. pinea stumps, the incidence of the pathogen was significantly higher in control stumps and in stumps treated with Proradix ${ }^{\circledR}$ and P. gigantea MUT $6212(88.6 \%)$ than in stumps treated with CFF and Rotstop ${ }^{\circledR}(59.1 \%)$ (Figure 1e). Urea performed significantly better than the other treatments (18.2\% incidence of the pathogen). All treatments reduced the area colonized by the pathogen compared to control stumps (Figure 1f). However, such a reduction was significant only for CFF, Rotstop ${ }^{\circledR}$ and urea $(7.1 \%, 5.7 \%$, and $0.6 \%$, respectively) (Figure $1 \mathrm{f}$ ).

Stumps of P. sylvestris treated and sampled were as follows: 24 control stumps sprayed with sterile water, 23 stumps treated with Proradix ${ }^{\circledR}, 24$ with CFF, 25 with P. gigantea MUT 6212, 24 with Rotstop ${ }^{\circledR}$ and 26 with urea. Isolates obtained from control stumps of $P$. sylvestris were all typed as $H$. annosum s.s. The incidence of the pathogen was significantly higher for control stumps, stumps treated with Proradix ${ }^{\circledR}$ and CFF (35.2\%) than for stumps treated with $P$. gigantea MUT 6212, Rotstop ${ }^{\circledR a n d}$ urea, which showed an incidence of $2.6 \%$ (Figure 1g). The area colonized by the pathogen in treated stumps was significantly lower than that in control stumps (20.6\%) for all treatments (Figure 1h). Treatment with P. gigantea MUT 6212 and with urea resulted in $0 \%$ and $0.1 \%$ areas colonized by the pathogen, respectively. Stumps treated with Proradix ${ }^{\circledR}$, CFF and Rotstop ${ }^{\circledR}$ resulted in $5.3 \%$, $2.4 \%$ and $1.3 \%$ areas colonized by the pathogen, respectively.

\subsection{Efficacy of Treatments on Logs of Pinus pinea}

Logs of $P$. pinea treated and sampled were as follows: 22 control logs sprayed with sterile water, 24 logs treated with Proradix ${ }^{\circledR}, 24$ with CFF, 23 with P. gigantea MUT 6212, 24 with Rotstop $^{\circledR}$ and 22 with urea. Isolates obtained from control logs of $P$. pinea were all typed as $H$. irregulare. Incidence and areas colonized by the pathogen on wood discs gathered from logs are shown in Figure 2. Barplots and dotcharts of Figure 2 were built as shown in Figure 1. The incidence of the pathogen in control logs and in logs treated with Proradix ${ }^{\circledR}$ was significantly higher $(84.7 \%)$ than that in logs treated with the other treatments $(26.8 \%)$ (Figure 2a). Significant reductions in the area colonized by the pathogen compared to control logs (9.5\% of area colonized) were observed for all treatments (Figure $2 b)$. In terms of the area colonized by the pathogen, CFF, P. gigantea MUT 6212 and Rotstop ${ }^{\circledR}$ performed significantly better than Proradix ${ }^{\circledR}$ and urea $(0.8 \%, 0.4$ and $0.2 \%$ vs. $1.7 \%$ and $1.0 \%$ of area colonized, respectively).

a)
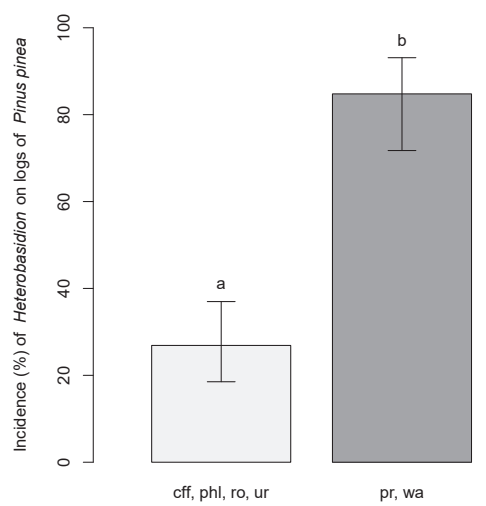

b)

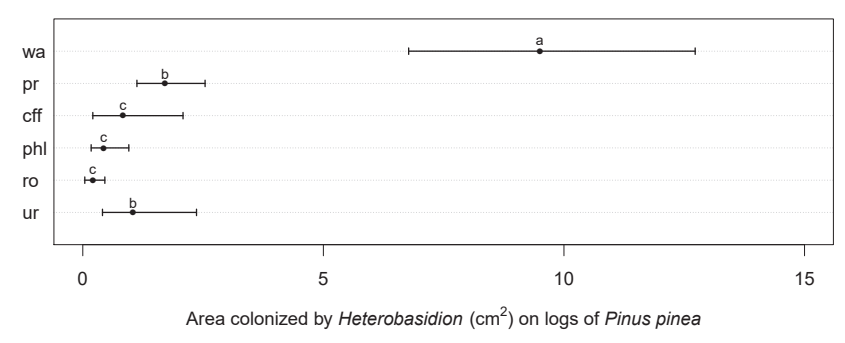

Figure 2. Barplots of the incidence (\%-panel (a)) and dotcharts of the areas colonized by Heterobasidion spp. $\left(\mathrm{cm}^{2}-\right.$ panel (b)) on treated logs of Pinus pinea. Treatment abbreviations: wa-water; pr-Proradix ${ }^{\circ}$; cff-cell-free filtrate; phl一Phlebiopsis gigantea MUT 6212; ro-Rotstop®; and ur-urea. For details, refer to the text. 


\subsection{Correlation between Stump Size and Efficacy of Treatments}

The correlations between stump size and the area colonized by Heterobasidion spp. on wood discs sampled from stumps are shown in Table 1. For P. abies, P. pinea, and P. sylvestris, there were no significant correlations, either in control or in treated stumps.

For A. alba, a significant correlation between stump size and the area colonized by the pathogen was observed in control stumps $(R=0.474 ; p=0.019)$ and in stumps treated with Proradix ${ }^{\circledR}(\mathrm{R}=0.447 ; p=0.037)$. The other treatments did not display significant correlations between the two variables.

Table 1. Pearson's correlation coefficient between stump size and the area colonized by Heterobasidion spp. on stumps of Abies alba, Picea abies, Pinus pinea and P. sylvestris treated with water (wa), Proradix ${ }^{\circledR}(\mathrm{pr})$, cell-free filtrate (cff), Phlebiopsis gigantea MUT 6212 (phl), Rotstop®(ro), and urea (ur). The symbol * marks significant correlation $(p<0.05)$.

\begin{tabular}{|c|c|c|c|c|c|c|}
\hline \multirow{2}{*}{ Host Tree Species } & \multicolumn{6}{|c|}{ Stump Treatments } \\
\hline & wa & pr & cff & phl & ro & ur \\
\hline A. alba & $\begin{array}{c}0.474^{*} \\
(p=0.019)\end{array}$ & $\begin{array}{c}0.447^{*} \\
(p=0.037)\end{array}$ & $\begin{array}{c}0.016 \\
(p=0.941)\end{array}$ & $\begin{array}{c}0.007 \\
(p=0.975)\end{array}$ & $\begin{array}{c}0.313 \\
(p=0.155)\end{array}$ & $\begin{array}{c}-0.315 \\
(p=0.163)\end{array}$ \\
\hline P. abies & $\begin{array}{c}0.220 \\
(p=0.313)\end{array}$ & $\begin{array}{c}0.250 \\
(p=0.261)\end{array}$ & $\begin{array}{c}-0.250 \\
(p=0.249)\end{array}$ & $\begin{array}{c}-0.177 \\
(p=0.406)\end{array}$ & $\begin{array}{c}-0.065 \\
(p=0.766)\end{array}$ & $\begin{array}{c}0.017 \\
(p=0.939)\end{array}$ \\
\hline P. pinea & $\begin{array}{c}0.055 \\
(p=0.794)\end{array}$ & $\begin{array}{c}-0.036 \\
(p=0.870)\end{array}$ & $\begin{array}{c}0.004 \\
(p=0.985)\end{array}$ & $\begin{array}{c}0.047 \\
(p=0.834)\end{array}$ & $\begin{array}{c}-0.248 \\
(p=0.264)\end{array}$ & $\begin{array}{c}0.017 \\
(p=0.941)\end{array}$ \\
\hline P. sylvestris & $\begin{array}{c}-0.230 \\
(p=0.278)\end{array}$ & $\begin{array}{c}-0.205 \\
(p=0.347)\end{array}$ & $\begin{array}{c}-0.323 \\
(p=0.122)\end{array}$ & $\begin{array}{c}\text { NA } \\
(p=\mathrm{NA})\end{array}$ & $\begin{array}{c}-0.067 \\
(p=0.757)\end{array}$ & $\begin{array}{c}-0.167 \\
(p=0.414)\end{array}$ \\
\hline
\end{tabular}

\section{Discussion}

In this study, four biological stump treatments (Proradix ${ }^{\circledR}, \mathrm{CFF}$, P. gigantea MUT 6212 and Rotstop ${ }^{\circledR}$ ) and one chemical treatment (urea) were tested against naturally occurring primary infections operated by all Heterobasidion species present in Europe, including the invasive $H$. irregulare, on their preferential hosts. Since the pioneering work of Rishbeth [43-46], who first elucidated the infection biology of the fungal pathogen and the potentiality of stump treatments for disease control, several studies have reported the effectiveness of stump treatments against primary infections of Heterobasidion spp. (see $[10,20,22,24,28,30,47]$ and literature therein), but only a few of them compared the efficacy of biological and chemical control agents, namely, urea, in the same experiments $[15,16,48]$. In addition, biological control with bacteria, although promising and effective in vitro against forest pathogens [33,49-51], have never been tested in the field thus far, with the exception of a pilot study conducted on a few P. abies stumps [31,32]. Overall, with the exception of Proradix ${ }^{\circledR}$ and P. gigantea MUT 6212 on P. pinea stumps, all biological and chemical treatments tested were effective in significantly reducing the area colonized by Heterobasidion spp. on stumps of the tested tree species compared to controls. Furthermore, the efficacy of treatments was not correlated with stump size, with Proradix ${ }^{\circledR}$ on $A$. alba stumps being the only exception.

The experiments were carried out in periods at high risk for primary infections of Heterobasidion spp. in the Alps (i.e., in summer and autumn) and in coastal regions of central Italy (i.e., in winter), based on previously published information on the availability of airborne inoculum or on the frequency of stump infections [9,10,52]. This allowed relying on natural airborne infections for the experiments, without the need for artificial inoculations of the pathogens. Indeed, results of the experiments suggest that the risk of stump infection by $H$. annosum s.l. may be relevant where treatments are not ordinarily carried out on freshly cut stumps. It was previously suggested that stump treatments are economically profitable when stump infection frequency in untreated stumps reaches or exceeds the threshold of $20 \%$ to $30 \%[53,54]$. In the present study, the incidence of the pathogen in control stumps ranged from $50 \%$ to $95.8 \%$ depending on tree species, thus recommending stump treatments in such situations. 
Study sites were pre-selected based on the availability of airborne inoculum of the Heterobasidion species commonly associated with the most abundant tree species in the forest stands. Indeed, all isolates obtained from control stumps in each stand were identified as belonging the Heterobasidion species predicted. Therefore, results of our treatment experiments on $A$. alba, $P$. abies, $P$. pinea and $P$. sylvestris stumps should be regarded as targeting-and hence, valid against-H. abietinum, $H$. parviporum, $H$. irregulare and $H$. annosum s.s., respectively. The above hosts grew in sites located either in the Alps (A. alba, $P$. abies, and P. sylvestris) or in the Mediterranean area (P. pinea). It is worth noting that most of the Italian forest stands harboring the tree species listed above are located in such ecoregions [41,42], although the distribution areas of A. alba, P. abies, P. sylvestris, and $P$. pinea across Europe overlap a wide range of forest types, habitats and ecosystems, whose environmental conditions (e.g., climate, soils, geographic position) and management practices may be highly variable [55-58]. Although the study sites we selected may be considered representative of the ecological and silvicultural conditions of two distinct and very different ecoregions, the Alpine and the Mediterranean, further studies replicating the same experiments in other ecoregions and areas of Europe (e.g., northern and eastern Europe) are needed to corroborate our core results, which are detailed below.

Overall, considering the results both in terms of the reduction in incidence of the pathogen and of the reduction in area colonized by the pathogen compared to controls, urea was the most effective treatment. This chemical treatment ranked either alone (on A. alba and P. pinea), or with other treatments (on P. abies and P. sylvestris) at the lower bound of incidence of Heterobasidion spp. Urea performed better than the other treatments in terms of areas colonized by the pathogen, although significance was observed only in the case of $A$. alba. The good performance of urea corroborated previous results obtained using wood discs of the same tree species in controlled conditions [33]. Urea has already been tested against Heterobasidion spp. with good results on stumps of A. alba, P. abies and $P$. sylvestris $[10,16,39]$, and also against $H$. annosum s.s. on stumps of $P$. pinea; however, this is the first report of the efficacy of urea against $H$. irregulare on stumps of such host species.

Rotstop $^{\circledR}$ was also shown to be rather effective against Heterobasidion spp. on stumps of several coniferous tree species, as expected based on a large body of literature and of its widespread use in practical forestry. However, our results should not be regarded as merely confirmatory. In fact, for the first time, this paper provides evidence about the efficacy of Rotstop $^{\circledR}$ on $A$. alba stumps. Furthermore, whereas previous experiments conducted with Rotstop $^{\circledR}$ on P. pinea stumps targeted H. annosum s.s. [20], this is first report of the efficacy of this treatment against $H$. irregulare on the same host. Adding some additional pieces of evidence on their efficacy, the results obtained with the commercial treatments against Heterobasidion spp. urea and Rotstop ${ }^{\circledR}$ could serve as references to appraise the performance of the newly tested treatments based on P. protegens strain DSMZ 13134 (i.e., Proradix ${ }^{\circledR}$ and CFF), and on P. gigantea MUT 6212 isolated from P. pinea in the H. irregulare invasion area. With the exception of $P$. pinea, the tested strain of $P$. gigantea performed as well as Rotstop ${ }^{\circledR}$ and, at least on some tree species, as well as urea. Surprisingly, results of P. gigantea MUT 6212 on P. pinea stumps, which we expected to be well adapted to the host in the Mediterranean region, were undistinguishable from those of untreated control stumps. The reason for this weak efficacy is unknown. Notable is the performance of this treatment especially on P. sylvestris. Although the efficacy of Rotstop ${ }^{\circledR}$ on P. sylvestris is in agreement with previous research conducted on the same host tree species in Latvia by Kenigsvalde et al. [23], treatment of P. sylvestris stumps with the P. gigantea MUT 6212 isolated from $P$. pinea was fully effective in preventing pathogen infections. Therefore, we can only speculate that either P. gigantea MUT 6212 is better adapted to P. sylvestris than to P. pinea, or it performs better when inoculated in summer and under Alpine environmental conditions. Although the two hypotheses are clearly not mutually exclusive, this study was designed to compare the performances of treatments on the same tree species and not across species; hence, the above inferences should be regarded as speculation. 
With the exception of applications on $A$. alba stumps, Proradix ${ }^{\circledR}$ failed in reducing the incidence of the pathogen compared to controls, although a significant reduction in the area colonized by the pathogens was observed on the stumps of most tree species. On the other hand, the CFF of P. protegens strain DSMZ 13134 performed as well as Rotstop ${ }^{\circledR}$ in reducing the incidence of the pathogen compared to controls, with the only exception being treatments on P. sylvestris. CFF of P. protegens strain DSMZ 13134 was comparable to the most effective state-of-the-art treatments (urea and Rotstop ${ }^{\circledR}$ ) in terms of reducing the areas colonized by the pathogen compared to control stumps, with the exception of $A$. alba. Overall, and with a few exceptions, CFF of P. protegens strain DSMZ 13134 performed better than Proradix ${ }^{\circledR}$, supporting previous observations conducted on wood discs under controlled conditions and pointing to a clear role played by antibiosis in the interaction of P. protegens strain DSMZ 13134 with Heterobasidion spp. [33]. Woodinhabiting bacteria and fungi may interact in a variety of ways, such as competing for low-molecular-weight compounds released by extracellular fungal enzymes, bacterial mycophagy or the production of toxic bacterial or fungal secondary metabolites [59], but very little is known about the above interactions [60,61]. Oligomers released during lignin degradation by basidiomycetes are appropriate substrates for most wood-inhabiting bacteria that can take advantage of the degradation activity of fungi [59]. In this way, fungi can be systematically deprived of a large part of their growth substrates [59]. By examining the results obtained on P. abies, P. pinea and P. sylvestris stumps, Proradix ${ }^{\circledR}$ was often able to reduce the spreading of the pathogen within stumps (i.e., area colonized by the mycelium), but not its occurrence on stumps (i.e., incidence). Therefore, Heterobasidion spp. might colonize wood more rapidly in comparison to P. protegens strain DSMZ 13134, by infecting stumps and starting its wood decay process, while the bacterium remains latently present. It should be noted that $P$. protegens strain DSMZ 13134 is a plant-growth-promoting rhizobacteria (PGPR) [62], and may be scarcely adapted to wood. Later, P. protegens strain DSMZ 13134 may release secondary metabolites in response to stress signals, thereby affecting Heterobasidion spp. Whether or not this scenario is realistic requires further investigations on the patterns of wood colonization by P. protegens strain DSMZ 13134 and on its interaction with Heterobasidion spp. Conversely, metabolites contained in the CFF of P. protegens strain DSMZ 13134 make this treatment ready to go against Heterobasidion spp. However, further research aimed at identifying the most active metabolites present in CFF is desirable, because it could lead to significant improvements in the performance of this biological treatment.

This paper is the first focusing on the effectiveness of biological and chemical stump treatments against the invasive $H$. irregulare on $P$. pinea, its main known host in Europe. In the framework of the recently released national regulatory control system for H. irregulare [63], data presented in this paper could guide National Plant Protection Organisations in the choice of the most appropriate product for containment. Urea, Rotstop ${ }^{\circledR}$, as well as CFF of $P$. protegens strain DSMZ 13134 are appropriate for this purpose, and hence can be used interchangeably, pending regulatory approvals. Surprisingly, CFF of P. protegens strain DSMZ 13134 performed as well as state-of-the-art treatments when applied on stumps of $P$. pinea, although this was not true when treatments were simulated on wood discs of P. pinea in controlled conditions [33]. Physical conditions differentiating wood discs and stumps, especially in terms of moisture, may have accounted for this. This finding confirms the need for field tests for the screening of biological control agents, as previously suggested [24].

Experiments carried out on P. pinea logs resulted in the good performance of treatments based on P. gigantea and on the CFF of P. protegens strain DSMZ 13134, and in a lower efficacy of urea and Proradix ${ }^{\circledR}$. A relatively low efficacy of urea on logs could be explained by the mechanisms of action of urea against Heterobasidion spp. In fact, the hydrolysis of urea leads to an increase in $\mathrm{pH}$ that prevents spore germination on the living tissues of the stump surface [18]; however, such tissues are expected to live shorter in logs than in stumps. Results of the experiment conducted on logs could contribute to the drafting of 
practical recommendations aimed at preventing infection and the subsequent fruiting of $H$. irregulare on wood residues, should residues be kept on-site for naturalistic purposes. It should be noted that several forests in the outbreak area of $H$. irregulare in Italy are either parks or a Site of Community Importance (SCI) that need to be managed appropriately.

No correlation was observed between stump size and the area colonized by H. annosum s.l. in treated stumps of P. abies, P. pinea and P. sylvestris. This finding supports the hypothesis that, generally, the performance of the treatments does not depend upon the stump size. However, a significant correlation between the two variables was found in A. alba in both untreated control stumps and stumps treated with Proradix ${ }^{\circledR}$. We cannot exclude that such correlation could have been favored by a longer incubation period of the pathogen on A. alba compared to the other tree species (8 months vs. 4 months), making a greater colonization of the fungus on stumps more likely, especially on control stumps and on stumps treated with poorly effective products.

Testing and comparing the efficacy of different stump treatments in the field is pivotal to fine-tune the management of Heterobasidion spp. in forest stands. Nonetheless, the availability of chemical or biological products with proven efficacy is not the only prerequisite needed to decide whether stump treatments could be profitably carried out, or not. In fact, a large body of literature suggests that the risk of stump infection should be assessed before applying treatments (see $[53,64,65]$ and the literature therein). Such risks may be highly dependent on climate and on seasonality, influencing the propagule deposition patterns of Heterobasidion spp. [9]. Hence, climate change may play an important role in the future by affecting the risk of stump infection by Heterobasidion spp. [66,67]. However, our experimental design was not conceived to implement decision-making processes about the opportunity of conducting stump treatments based on the risk of infection.

In conclusion, this paper provides new evidence supporting the good performances of Rotstop ${ }^{\circledR}$, and especially that of urea, against the three native Heterobasidion species on stumps of their preferential hosts and, for the first time, against the North American $H$. irregulare on stumps of $P$. pinea, which is currently a key host of this invasive pathogen in Europe. Although urea may not be longer available as a pesticide against H. annosum s.l. and Rotstop ${ }^{\circledR}$ is not approved for use in southern Europe, the CFF of P. protegens strain DSMZ 13134 appears a valid alternative to these two state-of-the-art treatments. This is relevant because this treatment, differently from the others, is based on antibiotics contained in a crude cultural cell broth, and could be further improved in terms of efficacy by identifying the active molecules and/or by optimizing their production or application, as previously suggested [33]. In more general terms, the possibility of using different treatments with comparable efficacy may lead to a higher acceptance by citizens of phytosanitary treatments in forests and could also minimize the ecological impact that a large-scale application of a single stump treatment may have.

\section{Materials and Methods}

\subsection{Study Sites and Treatments}

Stump treatment experiments were conducted in three forest stands in the north-west of Italy dominated by A. alba, P. abies and P. sylvestris, respectively, and in one P. pinea stand in central Italy (Table 2). Those forest stands are included in areas known to be infested by $H$. annosum s.l. [3,5]. The study sites in north-west of Italy were typical naturally regenerated, uneven-aged and mixed stands, harboring the relevant tree species in sizeable patches. The study site of central Italy (La Gallinara Park) was an even-aged plantation included in SCIs, preserving coastal Mediterranean habitats. The four study sites were pre-selected based on information on the Heterobasidion airspora pointing to the presence, in each stand, of the host-associated Heterobasidion species determined in previous studies by using the wood disc exposure method combined with the taxon-specific molecular typing of single spore isolates $[4,5,10]$. In each site, freshly cut stumps were created during selective thinnings carried out in the frame of the ordinary forest management. Thinnings were conducted on P. pinea at La Gallinara Park in January 2020, and on A. alba, P. abies and P. sylvestris in the 
study sites of north-west of Italy from June to September 2020 (Table 2). Before treatments, all freshly cut stumps were visually inspected for symptoms of wood decay caused by Heterobasidion spp., and only asymptomatic stumps were included in the experiments. Thinnings conducted at La Gallinara Park could only include a limited number of trees as prescribed by SCI-related forest regulations, logs deriving from branches of recently felled trees were also used as proxies to simulate $P$. pinea stumps. Logs were approximately 40-50 cm long, with a diameter of 9-33 cm and did not show any visible symptom of decay. Logs were placed upright in the $P$. pinea stand. The diameter of each stump and log was measured along two perpendicular directions on the upper cutting surface.

The efficacy of the following treatments was tested: Proradix ${ }^{\circledR}$ (SP Sourcon Padena $\mathrm{GmbH}$, Tübeningen, Germany), the CFF of P. protegens strain DSMZ 13134, a conidial suspension of $P$. gigantea MUT 6212 isolated from fruiting bodies on P. pinea at La Gallinara Park (Rome, Italy), the biocontrol product Rotstop ${ }^{\circledR}$ (Verdera Oy, Espoo, Finland), and aqueous urea (Fluka, Cologno Monzese, Italy) solution $(30 \% \mathrm{w} / \mathrm{v})$. P. protegens strain DSMZ 13134 was provided by SP Sourcon Padena GmbH (Tübeningen, Germany) and stored in Luria-Bertani (LB) broth amended with $30 \%$ glycerol at $-80{ }^{\circ} \mathrm{C}$. Fresh cultures were initiated from frozen stocks and refreshed in LB broth at $25^{\circ} \mathrm{C}$ for $24 \mathrm{~h}$ with shaking before use. CFF preparation was set up based on evidence showing that the antagonistic effect of $P$. protegens (strain DSMZ 13134) against Heterobasidion is maximum if CFF is obtained from a pure culture of P. protegens (strain DSMZ 13134) at $25^{\circ} \mathrm{C}$ [33]. Hence, the CFF was prepared by culturing $P$. protegens (strain DSMZ 13134) in LB broth with constant shaking for $24 \mathrm{~h}$ at $25^{\circ} \mathrm{C}\left(\mathrm{OD}_{600}\right.$ of 1.1). Cells were pelleted by centrifugation at $4000 \mathrm{rpm}$ for $10 \mathrm{~min}$, and the supernatant was filtered aseptically through a $0.22 \mu \mathrm{m}$ filter membrane to obtain CFF, free from bacterial cells. The strain of P. gigantea MUT 6212 was selected based on its good performances against Heterobasidion spp. in in vitro tests [40]. The conidial suspension of $P$. gigantea MUT 6212 was obtained by loading $500 \mu \mathrm{L}$ of sterile water on the surface of 7-day-old fungal colonies in $9 \mathrm{~cm}$ diameter Petri dishes previously incubated at $25{ }^{\circ} \mathrm{C}$ in the dark. The water was gently shaken and collected by using a pipette. The concentration of conidia in the suspension was assessed by using a Bürker chamber, and the conidial suspension was subsequently adjusted to $10^{4}$ conidia $\mathrm{mL}^{-1}$. The remaining stump treatments were prepared as described previously [33]. Control stumps received sterile water instead of treatments; we will refer to water as one of the six treatments.

Treatments were carried out manually by spraying the suspensions or solutions onto the surface of freshly cut stumps or logs within 1 hour after their cutting, until the surface became uniformly wet, i.e., an approximately $1 \mathrm{~mm}$ thick layer of suspension or solution. At least twenty replicate stumps were used for each treatment in each study site. A total of 135 stumps of $A$. alba, 125 of P. abies, 136 of P. pinea, and 146 of P. sylvestris were included in the experiments. A total of $139 \operatorname{logs}$ of $P$. pinea were used for the experiments, at least 20 for each treatment. For both stumps and logs, treatments were conducted according to a completely randomized design. 
Table 2. Main features of the study sites hosting the treatment experiments against Heterobasidion spp.

\begin{tabular}{|c|c|c|c|c|c|c|c|c|}
\hline Location & Latitude, Longitude & $\begin{array}{l}\text { Elevation } \\
\text { (m a.s.l.) }\end{array}$ & Host Tree Species & $\begin{array}{l}\text { Number of } \\
\text { Stumps }\end{array}$ & $\begin{array}{l}\text { Stump Diameter, } \\
\text { Min-Max (cm) }\end{array}$ & $\begin{array}{c}\text { Mean Stump } \\
\text { Diameter } \pm \text { SD (cm) }\end{array}$ & $\begin{array}{c}\text { Period of } \\
\text { Thinning/Treatments }\end{array}$ & Period of Sampling \\
\hline La Salle (AO) & $45.75667,7.07907$ & 1001 & A. alba & 135 & $10-70$ & $24.2 \pm 12.7$ & September 2020 & May 2021 \\
\hline Nus (AO) & $45.78494,7.45994$ & 1495 & P. abies & 125 & $9.5-110$ & $24.7 \pm 13.9$ & June-July 2020 & October-November 2020 \\
\hline La Gallinara Park (RM) & $41.53156,12.56187$ & 3 & P. pinea & 136 & $17-70$ & $39.1 \pm 11.0$ & January 2020 & May 2020 \\
\hline Nus (AO) & $45.77761,7.44911$ & 1495 & P. sylvestris & 146 & $6.5-76$ & $23.9 \pm 12.7$ & June-July 2020 & October-November 2020 \\
\hline
\end{tabular}




\subsection{Samplings and Laboratory Analyses}

Stumps and logs were sampled after 16 weeks from treatments, with the exception of stumps of $A$. alba, which were sampled after 32 weeks due to technical constraints (e.g., a snowy winter). Two 3-5 cm thick half-discs were cut from the top of each stump or log. The upper wood disc was discarded, while the second disc was taken to the laboratory for further analyses; the sampling was performed from one half of the stump or log surface. To avoid the computation of possible infections originating from roots, samples displaying visible symptoms of decay were discarded. The half-discs of stumps or logs were debarked, washed with tap water, and incubated for 10-14 days in plastic bags at room temperature with an optimal relative humidity for fungal growth [10]. Subsequently, the upper surface of the half discs was inspected under a dissecting microscope $(20 \times$ magnification) for the presence of typical Heterobasidion conidiophores, as previously described $[4,68]$. The area covered with Heterobasidion conidiophores was delimited with a marker and measured by using a transparent $1 \mathrm{~cm}$ grid. Measurements were expressed as $\mathrm{cm}^{2}$ of surface covered with Heterobasidion conidiophores.

To determine the species of Heterobasidion colonizing the disc surface, diagnostic assays were conducted on five randomly selected discs of control stumps or logs. Isolations were made under a dissecting microscope (20× magnification) with a needle by scraping the surface of conidiophores randomly chosen from the largest infection areas of the control disc. DNA extraction and species typing were conducted as previously described $[4,68]$.

\subsection{Statistical Analyses}

The incidence of Heterobasidion spp. for each host species and treatment was calculated in percentage as the ratio between the number of discs colonized by the pathogen and the total number of discs. The exact $95 \%$ confidence intervals associated with the incidence values were calculated as reported in Blaker [69]. The effects of the treatments on the incidence of Heterobasidion spp. were assessed separately for each host species. In the case of $P$. pinea, the analysis of data was conducted separately for stumps and logs. The treatments were compared by contrasting the incidence of Heterobasidion spp. with conditional inference tree models based on unbiased recursive partitioning algorithms [70,71]. The algorithms clustered the treatments based on the following criteria: (1) treatments exerting comparable effects on the incidence of Heterobasidion spp. (i.e., treatments resulting in incidence values not significantly different, $p>0.05$ ) were grouped within the same cluster; (2) treatments resulting in different effects on the incidence of Heterobasidion spp. (i.e., treatments associated with incidence values significantly different, $p<0.05$ ) were split in different clusters. Each cluster of treatments was characterized by an overall incidence value of Heterobasidion spp., with such values representing a proxy of the expected efficacy of the treatments.

The average area colonized by Heterobasidion spp. on the half-surface of stumps and logs was compared among treatments for each host species, separating the analysis of stumps and logs in the case of $P$. pinea. For the above average areas, the $95 \%$ bias-corrected and accelerated $(\mathrm{BCa})$ confidence intervals were calculated, as described in DiCiccio and Efron [72]. The above confidence intervals were obtained through the bootstrap iterative resampling method [73], as described in Lione et al. [74]. The comparisons between the average areas colonized by Heterobasidion spp. were carried out by running the algorithms fitting the unbiased recursive partitioning conditional inference tree models [70,71]. Algorithms were run on the identity function of the area colonized by Heterobasidion spp. as an outcome variable, and on the treatment as an input variable.

The correlation between the area colonized by Heterobasidion spp. on the half-surface of the stump and the stump diameter was assessed by testing the significance of the Pearson's correlation coefficient (R) [75]. The coefficient $R$ was calculated for each treatment and host species. 
Statistical analyses were conducted with $\mathrm{R}$ version 3.6.0 [76] and with the associated packages bootstrap [77], partykit [70], and binGroup [78]. The significance threshold was set to 0.05 for all tests.

Author Contributions: Conceptualization, M.P. and P.G.; methodology, M.P. and P.G.; formal analysis, G.L.; investigation, M.P., G.L. and S.O.; resources, P.G.; data curation, M.P. and G.L.; writingoriginal draft preparation, M.P.; writing—review and editing, G.L. and P.G.; visualization, G.L.; supervision, P.G.; funding acquisition, P.G. All authors have read and agreed to the published version of the manuscript.

Funding: This research was funded by SP Sourcon Padena $\mathrm{GmbH}$. This research was also partially supported by the European Union's Horizon 2020 research and innovation program under grant agreement no. 634179 (EMPHASIS).

Data Availability Statement: All data are reported in the manuscript.

Acknowledgments: The authors are grateful to the staff of the Gallinara Park (Rome, Italy) and the Dipartimento Risorse Naturali e Corpo Forestale/Département des Ressources Naturelles et Corps Forestier of Regione Autonoma Valle d'Aosta/Région Autonome Vallée d'Aoste for the logistic support and for helping with treatments and field samplings. A special thanks to Alessandro Porru, Flavio Vertui, Jean-Claude Haudemand and Giancarlo Zorzetto.

Conflicts of Interest: The funders had no role in the design of the study; in the collection, analyses, or interpretation of data; in the writing of the manuscript, or in the decision to publish the results.

\section{References}

1. Woodward, S.; Stenlid, J.; Karjalainen, R.; Hüttermann, A. Preface. In Heterobasidion Annosum: Biology, Ecology, Impact and Control; CAB International: Wallingford, UK, 1998; pp. xi-xii. [CrossRef]

2. Garbelotto, M.; Gonthier, P. Biology, epidemiology, and control of Heterobasidion species worldwide. Annu. Rev. Phytopathol. 2013, 51, 39-59. [CrossRef] [PubMed]

3. Gonthier, P.; Brun, F.; Lione, G.; Nicolotti, G. Modelling the incidence of Heterobasidion annosum butt rots and related economic losses in alpine mixed naturally regenerated forests of northern Italy. For. Pathol. 2012, 42, 57-68. [CrossRef]

4. Gonthier, P.; Nicolotti, G.; Linzer, R.; Guglielmo, F.; Garbelotto, M. Invasion of European pine stands by a North American forest pathogen and its hybridization with a native interfertile taxon. Mol. Ecol. 2007, 16, 1389-1400. [CrossRef] [PubMed]

5. Gonthier, P.; Anselmi, N.; Capretti, P.; Bussotti, F.; Feducci, M.; Giordano, L.; Honorati, T.; Lione, G.; Luchi, N.; Michelozzi, M.; et al. An integrated approach to control the introduced forest pathogen Heterobasidion irregulare in Europe. Forestry 2014, 87, 471-481. [CrossRef]

6. EPPO. Pest Risk Analysis for Heterobasidion irregulare; EPPO: Paris, France, 2015. Available online: http://www.eppo.int/ QUARANTINE/Pest_Risk_Analysis/PRA_intro.htm (accessed on 31 August 2021).

7. Brandtberg, P.O.; Johansson, M.; Seeger, P. Effects of season and urea treatment on infection of stumps of Picea abies by Heterobasidion annosum in stands on former arable land. Scand. J. For. Res. 1996, 11, 261-268. [CrossRef]

8. Cleary, M.R.; Arhipova, N.; Morrison, D.J.; Thomsen, I.M.; Sturrock, R.N.; Vasaitis, R.; Gaitnieks, T.; Stenlid, J. Stump removal to control root disease in Canada and Scandinavia: A synthesis of results from long-term trials. For. Ecol. Manag. 2013, $290,5-14$. [CrossRef]

9. Gonthier, P.; Garbelotto, M.; Nicolotti, G. Seasonal patterns of spore deposition of Heterobasidion species in four forests of the western Alps. Phytopathology 2005, 95, 759-767. [CrossRef]

10. Gonthier, P. Frequency of stump infections by Heterobasidion annosum s.l. and benefits from urea treatments vary with tree species and season in European Alpine forests. For. Ecol. Manag. 2019, 434, 76-86. [CrossRef]

11. Oliva, J.; Bernat, M.; Stenlid, J. Heartwood stump colonisation by Heterobasidion parviporum and H. annosum s.s. in Norway spruce (Picea abies) stands. For. Ecol. Manag. 2013, 295, 1-10. [CrossRef]

12. Asiegbu, F.O.; Adomas, A.; Stenlid, J. Conifer root and butt rot caused by Heterobasidion annosum (Fr.) Bref. Mol. Plant Pathol. 2005, 6, 395-409. [CrossRef] [PubMed]

13. Gonthier, P.; Thor, M. Annosus Root and Butt Rots. In Infectious Forest Diseases; Gonthier, P., Nicolotti, G., Eds.; CAB International: Wallingford, UK, 2013; pp. 128-158. [CrossRef]

14. Vasaitis, R.; Stenlid, J.; Thomsen, I.M.; Barklund, P.; Dahlberg, A. Stump removal to control root rot in forest stands. A literature study. Silva Fenn. 2008, 42, 457-483. [CrossRef]

15. Capretti, P.; Mugnai, L. Protezione delle ceppaie di pino dalle infezioni di Heterobasidion annosum. Inf. Fitopat. 1988, 38 , 49-51.

16. Nicolotti, G.; Gonthier, P. Stump treatment against Heterobasidion with Phlebiopsis gigantea and some chemicals in Picea abies stands in the western Alps. For. Pathol. 2005, 35, 365-374. [CrossRef]

17. Pratt, J.E.; Gibbs, J.N.; Webber, J.F. Registration of Phlebiopsis gigantea as a forest biocontrol agent in the UK: Recent experience. Biocontrol Sci. Technol. 1999, 9, 113-118. [CrossRef] 
18. Johansson, M.; Pratt, J.E.; Asiegbu, F.O. Treatment of Norway spruce and Scots pine stumps with urea against the root and butt rot fungus Heterobasidion annosum: Possible modes of action. For. Ecol. Manag. 2002, 157, 87-100. [CrossRef]

19. European Union Commission. Commission Implementing Regulation (EU) No 2021/745 of 6 May 2021 Amending Implementing Regulation (EU) No 540/2011; European Union Commission: Brussels, Belgium, 2021.

20. Annesi, T.; Curcio, G.; D'amico, L.; Motta, E. Biological control of Heterobasidion annosum on Pinus pinea by Phlebiopsis gigantea. For. Pathol. 2005, 35, 127-134. [CrossRef]

21. Brūna, L.; Klavina, D.; Zaluma, A.; Kenigsvalde, K.; Burnevica, N.; Nikolajeva, V.; Gaitnieks, T.; Piri, T. Efficacy of Phlebiopsis gigantea against Heterobasidion conidiospore and basidiospore infection in spruce wood. iForest 2020, 13, 369-375. [CrossRef]

22. Dumas, M.T.; Laflamme, G. Efficacy of two Phlebiopsis gigantea formulations in preventing Heterobasidion irregulare colonization of red pine stumps in eastern Canada. Phytoprotection 2013, 93, 25-31. [CrossRef]

23. Kenigsvalde, K.; Brauners, I.; Korhonen, K.; Zaluma, A.; Mihailova, A.; Gaitnieks, T. Evaluation of the biological control agent Rotstop in controlling the infection of spruce and pine stumps by Heterobasidion in Latvia. Scand. J. For. Res. 2016, 31, $254-261$. [CrossRef]

24. Lehtijärvi, A.; Doğmuş-Lehtijärvi, H.T.; Aday, A.G.; Oskay, F. The efficacy of selected biological and chemical control agents against Heterobasidion abietinum on Abies cilicica. For. Pathol. 2011, 41, 470-476. [CrossRef]

25. Rönnberg, J.; Sidorov, E.; Petrylaitè, E. Efficacy of different concentrations of Rotstop®and Rotstop ${ }^{\circledR S}$ and imperfect coverage of Rotstop®S against Heterobasidion spp. spore infections on Norway spruce stumps. For. Pathol. 2006, 36, 422-433. [CrossRef]

26. Sun, H.; Korhonen, K.; Hantula, J.; Asiegbu, F.O.; Kasanen, R. Use of a breeding approach for improving biocontrol efficacy of Phlebiopsis gigantea strains against Heterobasidion infection of Norway spruce stumps. FEMS Microbiol. Ecol. 2009, 69, 266-273. [CrossRef]

27. Sun, H.; Korhonen, K.; Hantula, J.; Kasanen, R. Variation in properties of Phlebiopsis gigantea related to biocontrol against infection by Heterobasidion spp. in Norway spruce stumps. For. Pathol. 2009, 39, 133-144. [CrossRef]

28. Zaluma, A.; Sherwood, P.; Bruna, L.; Skola, U.; Gaitnieks, T.; Rönnberg, J. Control of Heterobasidion in Norway Spruce Stands: The Impact of Stump Cover on Efficacy of Urea and Phlebiopsis gigantea and Implications for Forest Management. Forests 2021, 12, 679. [CrossRef]

29. Dovana, F.; Gonthier, P.; Garbelotto, M. Inter-and Intra-Continental Genetic Variation in the Generalist Conifer Wood Saprobic Fungus Phlebiopsis gigantea. Forests 2021, 12, 751. [CrossRef]

30. Blomquist, M.; Herrera, S.L.; Hofmann, J.; Beram, R.C.; Cleary, M.; Rönnberg, J. Size matters but is big always better? Effectiveness of urea and Phlebiopsis gigantea as treatment against Heterobasidion on Picea abies stumps of variable size. For. Ecol. Manag. 2020, 462, 117998. [CrossRef]

31. Gžibovska, Z. Evaluation of Phlebiopsis gigantea and Pseudomonas spp. for Biocontrol of Heterobasidion spp. in Norway Spruce. Master Thesis, Swedish University of Agricultural Sciences, Uppsala, Sweden, 2016.

32. Rönnberg, J.; Magazniece, Z. Potential "new" protective agents for biocontrol of Heterobasidion spp. on Norway spruce. In Proceedings of the LIFE+ ELMIAS Ash and Elm, and IUFRO WP 7.02.01 Program \& Book of Abstracts Root and Stem Rots Conference (LIFE-IUFRO), Uppsala, Sweden, 26 August-1 September 2018; p. 27.

33. Pellicciaro, M.; Lione, G.; Giordano, L.; Gonthier, P. Biocontrol potential of Pseudomonas protegens against Heterobasidion species attacking conifers in Europe. Biol. Control 2021, 157. [CrossRef]

34. Honkaniemi, J.; Piri, T.; Lehtonen, M.; Siipilehto, J.; Heikkinen, J.; Ojansuu, R. Modelling the mechanisms behind the key epidemiological processes of the conifer pathogen Heterobasidion annosum. Fungal Ecol. 2017, 25, 29-40. [CrossRef]

35. Piri, T.; Korhonen, K. Infection of advance regeneration of Norway spruce by Heterobasidion parviporum. Can. J. For. Res. 2001, 31, 937-942. [CrossRef]

36. Brūna, L.; Lione, G.; Kenigsvalde, K.; Burneviča, N.; Zaluma, A.; Klavina, D.; Gaitnieks, T.; Gonthier, P. Inferences on the Susceptibility of Wood of Different Tree Species to Heterobasidion annosum Sensu Lato Primary Infections and on the Range of Pathogen Spores Dispersal. Forests 2021, 12, 854. [CrossRef]

37. Gunulf, A.; Wang, L.; Englund, J.E.; Rönnberg, J. Secondary spread of Heterobasidion parviporum from small Norway spruce stumps to adjacent trees. For. Ecol. Manag. 2013, 287, 1-8. [CrossRef]

38. Holdenrieder, O.; Greig, B.J.W. Biological Methods of Control. In Heterobasidion Annosum Biology, Ecology, Impact and Control; Woodward, S., Stenlid, J., Karjalainen, R., Hüttermann, A., Eds.; CAB International: Wallingford, UK, 1998; pp. $235-258$.

39. Pratt, J.E.; Johansson, M.; Hüttermann, A. Chemical Control of Heterobasidion Annosum. In Heterobasidion Annosum Biology, Ecology, Impact and Control; Woodward, S., Stenlid, J., Karjalainen, R., Hüttermann, A., Eds.; CAB International: Wallingford, UK, 1998; pp. 259-282.

40. Albajes, R.; Madeira, F.; Vila, E.; Audsley, N.; Pugliese, M.; Gilardi, G.; Giordano, L.; Gonthier, P.; Sillo, F.; Gaile, I.; et al. Procedures for Locally Eradicating the Alien Heterobasidion Irregulare on Conifers in Report of the Most Effective BCAs for the Management of Target Pests. Deliverable D3.2 of the EMPHASIS Project Funded Under the European Union's Horizon 2020 Research and Innovation Programme Under GA No: 634179; WP3 Protection; Management, and Eradication; University of California: Berkeley, CA, USA, 2019; pp. 26-30. Available online: http:/ / www.emphasisproject.eu/deliverables.php (accessed on 31 August 2021).

41. Pignatti, S. I Boschi D'Italia-Sinecologia e Biodiversità; UTET: Turin, Italy, 1998.

42. Blasi, C.; Capotorti, G.; Copiz, R.; Guida, D.; Mollo, B.; Smiraglia, D.; Zavattero, L. Classification and mapping of the ecoregions of Italy. Plant Biosyst. 2014, 148, 1255-1345. [CrossRef] 
43. Rishbeth, J. Fomes annosus Fr. on pines in East Anglia. Forestry 1948, 22, 174-183. [CrossRef]

44. Rishbeth, J. Control of Fomes annosus Fr. Forestry 1952, 25, 41-50. [CrossRef]

45. Rishbeth, J. Stump protection against Fomes annosus: Treatment with substances other than creosote. Ann. Appl. Biol. 1959, 47, 529-541. [CrossRef]

46. Rishbeth, J. Inoculation of pine stumps against infection by Fomes annosus. Nature 1961, 191, 826-827. [CrossRef]

47. Motta, E.; Annesi, T.; D’Amico, L.; Curcio, G.; Sequino, S.; Scirè, M. Uso sperimentale di un isolato autoctono di Phlebiopsis gigantea: Efficacia ed ecosostenibilità. Forest 2009, 6, 148. [CrossRef]

48. Nicolotti, G.; Gonthier, P.; Varese, G.C. Effectiveness of some biocontrol and chemical treatments against Heterobasidion annosum on Norway spruce stumps. Eur. J. Plant Pathol. 1999, 29, 339-346. [CrossRef]

49. Azeem, M.; Barba-Aliaga, M.; Borg-Karlson, A.K.; Terenius, O.; Broberg, A.; Rajarao, G.K. Heterobasidion-growth inhibiting Bacillus subtilis A18 exhibits medium-and age-dependent production of lipopeptides. Microbiol. Res. 2019, 223, 129-136. [CrossRef]

50. Mesanza, N.; Iturritxa, E.; Patten, C.L. Native rhizobacteria as biocontrol agents of Heterobasidion annosum s.s. and Armillaria mellea infection of Pinus Radiata. Biol. Control. 2016, 101, 8-16. [CrossRef]

51. Mesanza, N.; Crawford, B.D.; Coulson, T.J.; Iturritxa, E.; Patten, C.L. Colonization of Pinus radiata D. Don seedling roots by biocontrol bacteria Erwinia billingiae and Bacillus simplex. Forests 2019, 10, 552. [CrossRef]

52. Garbelotto, M.; Linzer, L.; Nicolotti, G.; Gonthier, P. Comparing the influences of ecological and evolutionary factors on the successful invasion of a fungal forest pathogen. Biol. Invasions 2010, 12, 943-957. [CrossRef]

53. Möykkynen, T.; Miina, J.; Pukkala, T.; von Weissenberg, K. Modelling the spread of butt rot in a Picea abies stand in Finland to evaluate the profitability of stump protection against Heterobasidion annosum. For. Ecol. Manag. 1998, 106, 247-257. [CrossRef]

54. Wang, L.; Gunulf, A.; Pukkala, T.; Rönnberg, J. Simulated Heterobasidion disease development in Picea abies stands following precommercial thinning and the economic justification for control measures. Scand. J. For. Res. 2015, 30, 174-185. [CrossRef]

55. Mauri, A.; de Rigo, D.; Caudullo, G. Abies Alba in Europe: Distribution, Habitat, Usage and Threats. In European Atlas of Forest Tree Species; San-Miguel-Ayanz, J., de Rigo, D., Caudullo, G., Houston Durrant, T., Mauri, A., Eds.; Publications Office of the EU: Luxembourg, 2016; p. e01493b+.

56. Caudullo, G.; Tinner, W.; de Rigo, D. Picea Abies in Europe: Distribution, Habitat, Usage and Threats. In European Atlas of Forest Tree Specie; San-Miguel-Ayanz, J., de Rigo, D., Caudullo, G., Houston Durrant, T., Mauri, A., Eds.; Publications Office of the EU: Luxembourg, 2016; p. e012300+.

57. Abad Viñas, R.; Caudullo, G.; Oliveira, S.; de Rigo, D. Pinus Pinea in Europe: Distribution, Habitat, Usage and Threats. In European Atlas of Forest Tree Species; San-Miguel-Ayanz, J., de Rigo, D., Caudullo, G., Houston Durrant, T., Mauri, A., Eds.; Publications Office of the EU: Luxembourg, 2016; p. e01b4fct.

58. Houston Durrant, T.; de Rigo, D.; Caudullo, G. Pinus Sylvestris in Europe: Distribution, Habitat, Usage and Threats. In European Atlas of Forest Tree Species; San-Miguel-Ayanz, J., de Rigo, D., Caudullo, G., Houston Durrant, T., Mauri, A., Eds.; Publications Office of the EU: Luxembourg, 2016; p. e016b94+.

59. van Boer, W.; van der Wal, A. Interactions Between sSaprotrophic Basidiomycetes and Bacteria. In Ecology of Saprotrophic Basidiomycetes; Boddy, L., Frankland, J.C., van West, P., Eds.; Elsevier: Amsterdam, The Netherlands, 2008; pp. $143-153$.

60. Johnston, S.R.; Boddy, L.; Weightman, A.J. Bacteria in decomposing wood and their interactions with wood-decay fungi. FEMS Microbiol. Ecol. 2016, 92, 1-12. [CrossRef]

61. Kielak, A.M.; Scheublin, T.R.; Mendes, L.W.; Van Veen, J.A.; Kuramae, E.E. Bacterial community succession in pine-wood decomposition. Front Microbiol. 2016, 7, 1-12. [CrossRef] [PubMed]

62. Pseudomonas sp. DSMZ 13134. Available online: https://en.sourcon-padena.de/proradix-section/pseudomonas-page.html (accessed on 31 August 2021).

63. European and Mediterranean Plant Protection Organization. Heterobasidion irregulare: Procedures for official control. EPPO Bull. 2020, 50, 142-147. [CrossRef]

64. Pratt, J.E. Stump Treatment against Fomes. Forest Research Annual Report and Accounts 2001-2002; Forestry Commission, The Stationary Office: Edinburgh, UK, 2002; pp. 76-85.

65. Redfern, D.B.; Pratt, J.E.; Hendry, S.J.; Low, J.D. Development of a policy and strategy for controlling infection by Heterobasidion annosum in British forests: A review of supporting research. Forestry 2010, 83, 207-218. [CrossRef]

66. Terhonen, E.; Langer, G.J.; Bußkamp, J.; Răscuţoi, D.R.; Blumenstein, K. Low water availability increases necrosis in Picea abies after artificial inoculation with fungal root rot pathogens Heterobasidion parviporum and Heterobasidion annosum. Forests 2019, 10, 55. [CrossRef]

67. Venäläinen, A.; Lehtonen, I.; Laapas, M.; Ruosteenoja, K.; Tikkanen, O.P.; Viiri, H.; Ikonen, V.-P.; Peltola, H. Climate change induces multiple risks to boreal forests and forestry in Finland: A literature review. Glob. Chang. Biol. 2020, 26, 4178-4196. [CrossRef]

68. Gonthier, P.; Garbelotto, M.; Varese, G.C.; Nicolotti, G. Relative abundance and potential dispersal range of intersterility groups of Heterobasidion annosum in pure and mixed forests. Can. J. Bot. 2001, 79, 1057-1065. [CrossRef]

69. Blaker, H. Confidence curves and improved exact confidence intervals for discrete distributions. Can. J. Stat. 2000, 28, 783-798. [CrossRef]

70. Hothorn, T.; Zeileis, A. Partykit: A modular toolkit for recursive partytioning in R. J. Mach. Learn. Res. 2015, 16, 3905-3909. 
71. Hothorn, T.; Hornik, K.; Zeileis, A. Unbiased recursive partitioning: A conditional inference framework. J. Comput. Graph. Stat. 2006, 15, 651-674. [CrossRef]

72. DiCiccio, T.J.; Efron, B. Bootstrap confidence intervals. Stat. Sci. 1996, 11, 189-228. [CrossRef]

73. Carsey, T.M.; Harden, J.J. Monte Carlo Simulation and Resampling Methods for Social Science; SAGE Publications Inc.: Thousand Oaks, CA, USA, 2014. [CrossRef]

74. Lione, G.; Giordano, L.; Turina, M.; Gonthier, P. Hail-induced infections of the chestnut blight pathogen Cryphonectria parasitica depend on wound size and may lead to severe diebacks. Phytopathology 2020, 110, 1280-1293. [CrossRef] [PubMed]

75. Crawley, M.J. The R Book, 2nd ed.; John Wiley \& Sons: Chichester, UK, 2013. [CrossRef]

76. R Core Team. R: A Language and Environment for Statistical Computing; R Foundation for Statistical Computing: Vienna, Austria, 2019. Available online: https:/ / www.R-project.org/ (accessed on 31 August 2021).

77. Efron, B.; Tibshirani, R.J. An Introduction to the Bootstrap. S Original, from StatLib and by Rob Tibshirani. R Port by Friedrich Leisch. (2019). Bootstrap: Functions for the Book "An Introduction to the Bootstrap"; R Package Version 2019.6; CRC Press: Boca Raton, FL, USA, 1994. Available online: https:/ /CRAN.R-project.org/package=bootstrap (accessed on 31 August 2021).

78. Zhang, B.; Bilder, C.; Biggerstaff, B.; Schaarschmidt, F.; Hitt, B. Evaluation and Experimental Design for Binomial Group Testing; R Package Version 2.2-1; binGroup: Istanbul, Turkey, 2018. Available online: https: / CRAN.R-project.org/package=binGroup (accessed on 31 August 2021). 